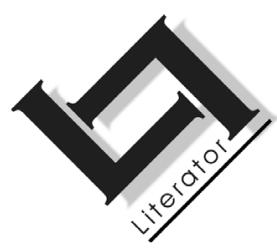

\title{
Die sin as narratiewe kode in "Die uur van die idiote" deur Abraham H. de Vries
}

\author{
M.J. Prins \\ Universiteit van Fort Hare \\ PORT ALFRED \\ E-pos: michielp@mweb.co.za
}

\section{Abstract \\ The sentence as narrative code in "Die uur van die idiote" ("The hour of the idiots") by Abraham H. de Vries}

This article focuses on the following aspects of syntax in "Die uur van die idiote" by Abraham H. de Vries: word and phrase repetition, enumeration, omission (ellipsis), word order, rhythm, length and composition, and sound repetition. Through word and phrase repetition the ironic situation in which the characters find themselves is made relevant, as well as their frustration and mutual powerlessness. Enumeration also is an agent of irony, more specifically irony created by the contrast between material fullness and existential emptiness, as well as of the fact that the characters are consumer items inside a metaphorical prison in which there is a lack of humaneness. Through ellipsis the disillusionment of the central character is communicated, as well as the enigmatically uncertain relationship between him and his wife, contrasting with her conviction that love is still possible between them. It also demonstrates the objectification of the human being. Change in word order is connected to the paradigm of dehumanisation, but also indicates the conviction that existential liberation is after all possible. This also leads to a climax. Rhythm communicates the themes of irony and existential bewilderment. It also serves as an emotional code for the existential crisis of the characters. Sentence length and composition emphasise a disturbed relationship, existential imprisonment and the sometimes helpless cynicism of the central character. Through sound repetition the reader's attention is focused on concepts that are important for the meaning of the story. 


\section{Opsomming}

\section{Die sin as narratiewe kode in "Die uur van die idote" deur Abraham H. de Vries}

In hierdie artikel word gefokus op die volgende aspekte van die sinshantering in "Die uur van die idiote" deur Abraham $\mathrm{H}$. de Vries: woord- en fraseherhaling, enumerasie, weglating (ellips), woordorde, ritme, lengte en samestelling, en klankherhaling. Deur herhaling word die ironiese situasie waarin die karakters hulle bevind, gereleveer, asook hulle frustrasie en wedersydse magteloosheid. Enumerasie staan eweneens in diens van die ironie, meer bepaald ironie wat geskep word deur die teenstelling tussen materiële volheid en eksistensiële leegheid, asook van die feit dat die karakters verbruiksartikels is binne 'n metaforiese tronk waarin daar gebrek aan medemenslikheid is. Deur ellips word die sentrale karakter se ontnugtering gekommunikeer, asook die enigmaties-onsekere verhouding tussen hom en sy vrou, maar daarteenoor ook haar oortuiging dat liefde tóg nog tussen hulle moontlik is. Verder demonstreer dit die versaakliking van die mens. Woordordewysiging sluit aan by die paradigma van ontmensliking, maar dui ook op die oortuiging dat eksistensiële bevryding tóg moontlik is. Dit loop ook uit op 'n klimaks. Ritme staan in diens van die temas van ironie en eksistensiële ontreddering. Dit dien ook as emosionele kode vir die karakters se eksistensiële krisis. Sinslengte en -samestelling releveer 'n versteurde verhouding, asook eksistensiële gebondenheid; verder ook die soms magtelose sinisme van die sentrale karakter. Deur klankherhaling word die leser se aandag gevestig op begrippe wat vir die strekking van die verhaal belangrik is.

\section{Inleiding}

Terwyl daar in die poësieteorie deeglik gefokus word op die vers en strofe as basiese strukturele segmente van die gedig, is daar in die narratologie wat die ooreenkomstige segmente in die prosateks, naamlik die sin en die paragraaf, betref 'n verbasende stilswye. 'n Uitsondering hierop is Hans du Plessis se lemma sintaksis (van die prosa) in Literêre terme en teorieë (Cloete, 1992:493-495), waarin hy verklaar: "... sintaktiese analise van die literêre teks op grond van die wetenskaplike linguïstiese feite lewer ' $n$ wesenlike bydrae tot die uiteindelike literêre interpretasie van 'n teks". Du Plessis vestig verder die aandag op die volgende aspekte van 'n sintaktiese benadering van die literêre teks: die beskrywing van die sinstruktuur sal ook vereistes van die kommunikatiewe struktuur, soos temakeuse, topiek, vooronderstelling, spreker-hoorder-konvensies, voor- en agter- 
grond, ensovoorts in berekening bring. Dit gaan in die sintaktiese prosa-analise nie net om die interne bou-elemente en hulle onderlinge verhoudings nie, maar juis ook om die analise van die sin na buite: die verband tussen sinne onderling en dié tussen die sin en die groter geheel. Die sintaktiese struktuur van die teks het direkte invloed op die aktiwiteit van lees - dit kan die leser in sy voortgang óf vertraag óf versnel - waardeur die leser se aandag afgetrek word van sekere gegewens of dan juis gevestig word op ander gegewens. Een van die belangrikste sintaktiese middels in die hand van die prosaskrywer in 'n taal soos Afrikaans, bly volgorde. Ekwivalente sinsvolgorde is nie net bindingsmiddel nie, sintaktiese volgorde of die ophef van "gewone" volgorde is juis een van dié belangrikste nadruksmiddels in Afrikaans. Die volgorde van sinstukke en sinne binne die prosateks kan natuurlik eenvoudig gebruik word om die opeenvolging van handelinge/gebeure in die tyd aan te gee. Neutrale sintaktiese en morfologiese gegewens het in die taalaanbod ' $n$ betreklik lae kommunikatiewe funksie. Die kommunikatiewe gewig van 'n element in die taalaanbod hou direk verband met keuse. Die neutrale, "gewone", subjek-/verbum-/objektiefhoofsinvolgorde gee aan die elemente in so 'n sin weinig meer as neutrale kommunikatiewe gewig. Sodra hierdie volgorde opgehef word, word 'n nuwe kommunikatiewe verwagting by die leser geskep. Die graad van kommunikatiewe dinamiek van die elemente in die neutrale sin is veel laer as dié van die elemente in ' $n$ sin waarvan die woordorde van die neutrale afwyk. Plasing is een van die belangrikste nadruksmiddels in Afrikaans. Hierdeur word elemente na 'n fokusposisie verskuif of juis daaruit verskuif, en deur die sintaktiese analise van die sinsvolgorde kan die teks vir die leser/kritikus oopgemaak word.

In hierdie studie word aan meer aspekte van die sintaksis aandag gegee as slegs aan die sintaktiese struktuur.

In sy bespreking van Abraham $\mathrm{H}$. de Vries se oeuvre in Perspektief en profiel merk Du Toit (1998:388) op: "Soos by Aucamp en Barnard is daar ook by De Vries 'n poëtisering ....' 'n Manifestasie van hierdie aspek van De Vries se werk is sy hantering van die sin. In sy commendatio by die toekenning van die ereburgerskap van Ladismith aan Abraham H. de Vries maak Van Zyl (2007:26) die stelling dat De Vries die "vermoë (het) om Afrikaanse sinne te maak op 'n manier wat baie van sy medeskrywers groen van jaloesie laat verkleur". Die doel van hierdie artikel is om die geldigheid van bostaande bewerings te illustreer aan die hand van die hantering van die sin as narratiewe kode in "Die uur van die idiote", wat beskou word as een van De Vries se belangrikste verhale en wat 
ook eksemplaries is van sy skryfstyl, spesifiek wat sintaksis betref. In sy resensie van die betrokke kortverhaalbundel (Die uur van die idiote) bestempel Smuts (1985:55) dit as (in daardie stadium) "een van die beste kortverhale binne De Vries se oeuvre en daarom binne die Afrikaanse kortverhaalliteratuur". Daar sal op die volgende aspekte van die sinshantering in genoemde verhaal gefokus word: woord- en fraseherhaling, enumerasie, weglating, woordorde, ritme, lengte en samestelling en klankherhaling.

\section{Aspekte van die sinshantering}

\subsection{Woord- en fraseherhaling}

Die verhaal begin só: "Nie 'n see nie (and a star to steer me by), nee, in die stad was daar nie 'n see nie, maar om die huis was daar ook nie 'n heining van gegote ystertralies nie," (p. 9). ${ }^{1}$ Hierdie sin is 'n weefsel van woord- en fraseherhaling. Daar is herhaling van die ontkennende frase "nie ... nie", wat verder beklemtoon word deur die bywoord "nee", van die woord "see" en van die frase "was daar". Die reeks "nie 'n see nie/nie 'n see nie/nie 'n heining ... nie" suggereer ' $n$ ironiese kontras wat vir die situasie in die verhaal veelseggend is. Die manlike karakter wat ons in die eerste paragraaf ontmoet, het klaarblyklik die verhuising na die stranddorp as 'n soort bevryding gesien. Maar juis hier is daar "' $n$ heining van gegote ystertralies" om die huis. Die sinsgedeelte wat na maar volg, dui op 'n ironiese teenstelling: hoewel hulle die huis by die see klaarblyklik as 'n ruimte van groter vryheid beskou het, is dit in werklikheid 'n soort gevangenis. So word genoemde karakter reeds die eerste werklike "idioot" in die verhaal.

Ook die herhaling van see in die aanvangsin is funksioneel. Die see keer as simbool later in die verhaal terug: gedurende die aandpartytjie daal daar 'n stilte neer waarbinne "die harde slae van die see teen die rotse met tussenpose hoorbaar word" (p. 15). Hierdie partytjie kan ook as 'n soort "uur (byeenkoms) van die 'idiote' bestempel word. Die vol ruimte waarbinne die personasies hulle hier bevind, is op ironiese wyse "leeg" - simbolies van 'n eksistensiële gevangenisskap, waarvan die "harde slae van die see teen die rotse" simbool word. In Kortom2 (De Vries, 1989:74) word die see "met sy tydlose beweging" bestempel as "die kontrasbeeld van nimmereindigende

$1 \quad$ Verwysings wat slegs 'n bladsynommer bevat, verwys na De Vries (1984). 
maar ook gevange beweging teenoor die beperking van menslike bestaan en uitsigte".

Die herhaling van was daar dien as snoer waaraan die ruimtelike gegewens see en heining (simbole van gevangenisskap) gejukstaponeer word.

Die man en vrou in die verhaal bevind hulle in 'n disfunksionele huwelik, wat bydra tot hulle "idiootskap". Die vrou is baasspelerig. (Haar pa se raad aan haar was dat 'n mens ander net kan beheer as jy jouself kan beheer.) Dit word ook gesuggereer deur die mededeling dat "hulle (sy) die plek uitgekies het", asook deur die feit dat in die gedeeltes uit die Hemingway-teks wat hy onderstreep het na "Your (die vrou se - MJP) bloody money" verwys word. Hieruit kan 'n mens aflei dat hulle die huis gekoop het met geld wat die vrou gehad het. Verder lui die Hemingway-gedeelte: “... I've done what you wanted me to do. But I wish we'd never come here". Hierdie woorde word, ironies genoeg, in die aangehaalde teks deur die vrou geuiter, maar artikuleer die man se gevoelens. Daarteenoor voel die vrou weer magteloos teenoor sy paranoïese skuldgevoel.

Hierdie emosies van frustrasie en wedersydse magteloosheid word deur woordherhaling oorgedra. Die man het sy onderstreping gedoen met "'n potlood ('n draaipotlood wat sy vir hom gegee het)". Die herhaling van potlood dui op sy opstandigheid jeens haar groter welvarendheid. Nadat sy die onderstreepte woorde gelees het, sê sy vir haarself: "Hy het dit nie met opset gedoen nie [...] Hy het nie geweet sy sal die boek optel nie. Hy doen so min dinge in die laaste tyd met opset." Die herhaling van hy, het nie en met opset dramatiseer die spanning tussen die vrou se frustrasie en haar strewe om haarself te beheer.

\subsection{Enumerasie}

Met enumerasie bedoel ek die opnoem van 'n reeks gegewens binne dieselfde of opeenvolgende sinsverband, as gevolg waarvan 'n sekere verband daartussen geïmpliseer word. Hierdie stylfiguur speel ook 'n belangrike en funksionele rol in "Die uur van die idiote".

Reeds in die eerste fase van die vertelling kom dit voor: "Binne lyk die huis byna bekend, die meubels, die gordyne, die skilderye" (p. 9). Twee paragrawe verder: "Die boeke, die skryftafel, die liasseerkabinet in sy studeerkamer, die Breughel-afdruk bokant die kaggel, alles is bekend, maar teen die laatmiddag, as die mis van die see se kant af begin opkruip, slaan die vensters aan die binnekant 
aan, selfs al brand die vuur" (p. 10). Die karakters (welvarende mense) bevind hulle in 'n ruimte vol bekende besittings, wat 'n ironiese kontras vorm met die eksistensiële leegheid wat hulle ervaar as gevolg van die gebrek aan liefde tussen hulle. In Kortom2 (De Vries, 1989:74) word "Die uur van die idiote" getipeer as "in breë sin 'n metafoor vir die bestaan van die mens: vasgevang in 'n steriele oomblik". In hierdie opsig is die woord maar in die tweede sin van besondere belang. Die enumerasie in die eerste helfte van die sin beklemtoon die weelde aan bekende besittings, terwyl die tweede helfte die ruimte as 'n soort gevangenis (sonder uitsig na buite) aandui. Metafories gesproke, bring die vuur geen oplossing vir die afstandelike verhouding tussen die man en sy vrou nie.

Die enumerasietegniek bereik 'n hoogtepunt in die sin wat op p. 14 begin met "Nadat Bester en Marie gepraat het" en op p. 15 eindig met "met tussenposes hoorbaar word". Hierdie sin begin met 'n enumerasie van die gespreksonderwerpe tydens die byeenkoms. Daarna volg enumerasies van aspekte van die toneel aan tafel, die beroepe van die gaste, aspekte van die skamel ruimte buite. Dan word teruggekeer tot die rykmanswêreld binne die huis, daarna volg die reeks dinge wat dui op sekuriteit sowel as welvaart, om te eindig met "die harde slae van die see teen die rotse (wat) met tussenpose hoorbaar word". Deur die enumerasie word gefokus op die ironiese oënskynlike volheid van hierdie ruimte, wat in werklikheid leeg is. Dit is 'n ruimte vol banale gespreksonderwerpe, kos en luukse besittings, professionele en onprofessionele mense. Binne hierdie ruimte raak die trietsige buitewêreld "vergete". Die artistiek-kulturele mond egter uit in psigiese onvervuldheid (verlange). As gevolg daarvan "(word) die harde slae van die see teen die rotse met tussenpose hoorbaar", waardeur die vryheidsdrang van hierdie "idiote" ("die teenstelling tussen wat (die karakters) begeer en waarna hulle vrugteloos uitreik" - Smuts, 1985:54) geaktiveer word. Dit word metafories gekommunikeer deur die kontras tussen see en stadsruimte. Hierdie buitengewoon lang, enumeratiewe sin word op funksioneeldramatiese wyse in paragrawe verdeel deur die tydsaanduidende woorde Nadat, toe, terwyl en begin. Kannemeyer (1983:452) het reeds opgemerk dat die "opstapeling van bywoordelike bysinne van tyd [...] besonder effektief (is)".

Tydens die partytjie dink die afgetrede nuusredakteur aan Jana wat die motivering gehad het om weg te kom uit die kring van die idiote na die ruimte van die (egte) liefde. Hy kom dan tot die slotsom: "Dis waarop ons almal wag." (p. 15.) Dan fokus hy weer op sy gaste: "Drie maande, en die patroon is al bekend; julle het almal net ander 
name en ander gesigte, maar julle is soos melkbottels, soos buisies tandepasta, soos motors van dieselfde fabrikaat" (p. 15). Hulle is ook metafories gesproke blote verbruiksartikels, soos deur die enumerasie daarvan in die hierbo aangehaalde sin te kenne gegee word. Hulle is, soos hyself ook, "slagoffers van 'n liefdelose en materialistiese bestel waaraan daar in werklikheid geen einde kan kom nie" (Smuts, 1985:55).

Nadat hulle gaste vertrek het, sien die sentrale karakter voor sy geestesoog hoe die bouer, die huisvrou, die bankbestuurder, die tandarts, die aktrise en die prokureur besig is om fiksheidsoefeninge in 'n sauna te doen (p. 16). Deur die enumerasietegniek word op hulle beroepe gefokus, waardeur iets van 'n dehumaniserende perspektief tot stand kom. Hierdie mense is as 't ware gevangenes van hulle ampte ("idiote"), selfs wanneer hulle met iets heeltemal anders besig is. Kannemeyer (1983:452) bestempel hierdie passasie (tesame met dié van die winkende jong meisie) as "een van die hoogtepunte in De Vries se oeuvre". Wanneer die sentrale karakter in sy visioen probeer om die deur oop te kry, help niemand hom nie, "nie die medikus of die garage-eienaar of die kruidenier nie" (p. 16). Hy bevind hom saam met hulle in 'n metaforiese tronk waarin daar 'n gebrek aan medemenslikheid is. Daar is 'n funksionele patroon in die beroepe wat in die bostaande aanhaling geënumereer word. Die eerste twee (medikus en garage-eienaar) staan in verband met ampte wat (in dalende orde) daarop bereken is om mense te help wat in nood verkeer. Die satiries-amusante dalende orde in die enumerasiereeks bereik 'n (laagte-) hoogtepunt in die verwysing na die kruidenier, wat ingestel is op die bloot materieel-biologiese behoeftes van die mens. Niemand help nie, nie die "hoëres" nie, en ook nie die "laeres" nie.

\subsection{Weglating (ellips)}

In 'n sekere sin is ellips ("weglating van woorde wat veronderstel kan word"; HAT, 2000:203) die teenoorgestelde van enumerasie. Terwyl enumerasie as oordadigheid beskou kan word, is weglating 'n soort ekonomie. Carstens (1997:243) omskryf die begrip ellips soos volg:

Ellips kom dus voor wanneer iets wat struktureel noodsaaklik is, nie werklik leksikaal uitgedruk word in die teks nie; daar is gevolglik ' $n$ aanduiding van onvoltooidheid (incompleteness) ten opsigte van die betrokke struktuur in die teks. Die spreker/skrywer glo dat die aangesprokene wel in staat sal wees om dié 'tekort' aan te vul en ook korrek te begryp met 
verwysing na ander elemente wat reeds in die teks (meestal in dieselfde $\sin$ ) aanwesig is. Daar is met ander woorde 'n presupposisie in die teks aanwesig dat 'n mentale aanvulling nodig is om die sin goed te kan verstaan.

Die eerste sin van "Die uur van die idiote" met sy herhaling word gevolg deur 'n bondige een: "Boonop swart geverf" (p. 9), waarin die koppelwerkwoord was en die verwysende voornaamwoord dit weggelaat is. Die weglating van was en dit sowel as die gebruik van die verlede deelwoord geverf verleen iets staties (doods) daaraan. Die sentrale karakter se ontnugtering met sy gewaande ruimte van vryheid (die geromantiseerde huis by die see) word effektief gekommunikeer deur dié saaklik-bondige elliptiese sin. Dit word verder beklemtoon deur die verwysing na die kleur swart, wat volgens De Vries (1984:50) onder meer "anything to do with death, mourning, penitence, punishment (in Hell)" kan simboliseer.

Die volgende opvallende voorbeeld van ellips kom voor in die eerste sin van die vierde paragraaf van die verhaal: "Drie maande, en alles het al weer bekende patrone begin aanneem." (p. 9.) Hierdie sin is 'n verkorting van "Drie maande gelede het húlle hier ingetrek" in die derde paragraaf. Deur die herhaling van hierdie woorde, tesame met die weglating van die res van die betrokke konstruksie, word die feit dat hulle drie maande tevore ingetrek het, emosioneel gelaai. Die sentrale karakter se ontgogeling met sy nuwe wêreld het gou begin. Op p. 15 word die betrokke ellips herhaal: "Drie maande, en die patroon is al bekend; julle het net ander name en ander gesigte, maar julle is soos melkbottels, soos buisies tandepasta, soos motors van dieselfde fabrikaat." Hierdeur word die spoed waarteen die sentrale karakter weer slagoffer van die verbruikerskultuur geword het, sterker geaksentueer. Hierdie fokus op die tydsdimensie mond uiteindelik uit, en bereik 'n emosionele klimaks, in die drie opeenvolgende elliptiese sinne op p. 17: "Wanneer? Wanneer? Hoe lank nog?"

Wanneer die sentrale karakter sy voorneme uitspreek om te gaan kyk of die vissersbote uit is om te gaan visvang, vermaan sy vrou hom om 'n serp om sy nek te sit, belowe tee wanneer hy terugkom en steek haar hand uit toe hy verbystap, "maar hy maak asof hy dit nie gesien het nie. Sy laat haar kop sak en begin weer in die tydskrif blaai." (p. 10.) Die hieropvolgende paragraaf begin dan met dié elliptiese sin: "Melodrama, dink hy," (p. 10), wat sy afstotende (mens kan byna sê blaffende) respons op haar poging om (letterlik sowel as figuurlik) hand uit te steek effektief kommunikeer, geaksentueer deur die kort daaropvolgende sin: "Jy kan dit bekostig". Ook die derde sin 
in hierdie paragraaf is ellipties: "As iets eendag moes gebeur wat die emosie uit jou sal uitpers, dan - maar hy weet nie wat dan nie." So enigmaties-onseker het die verhouding tussen hierdie twee getroudes geword dat hy nie eers hipoteties kan verklaar watter uitwerking 'n emosionele uiting van haar kant af daarop sal hê nie.

Wanneer hy vertrek het, tel sy die boek op "waarin hy gesit en lees het: Hemingway" (p. 10). Weer kommunikeer die saaklike eenwoordsin iets van die feit dat emosie heeltemal uit hierdie huwelik verdwyn het. Hulle is ook vasgevang in hulle eie "uur van die idiote", die tyd wanneer die gebrek aan medemenslikheid jeens die medemens (waardeur van die mens slegs 'n middel tot 'n doel gemaak word), aan die lig kom, soos ook gedemonstreer deur die feit dat die meisie op Oudtshoorn die vorige week blykbaar in die "uur van die idiote" vermoor is.

Teenoor hierdie moord staan die regte soort moord waarna in die Hemingway-aanhaling verwys word wat deur die vrou onderstreep word: "That's the good destruction. That's the way we were made to be destroyed ..." (p. 11), 'n liefdesmoord dus. Hierna volg die volgende gedeeltelik elliptiese sin: "Ondanks, dink sy 'n bietjie wrang, ondanks, want sy is jonk en sy weet dat sy nie onaantreklik is nie" (p. 11). Ons het hier 'n kombinasie van weglating en herhaling. Die herhaling beklemtoon die vrou se oortuiging dat (erotiese) liefde tóg nog tussen hulle moontlik is en deur die ellips word die allesomvattendheid van haar oortuiging (die ongespesifiseerde waarna ondanks verwys) benadruk. Dit is veelseggend dat ondanks in die gelade, uitgesponne sin op p. 14-15 terugkeer, waar dit aan die begin van een van die paragrawe (p. 137) staan waarin die betrokke sin opgedeel is: "Ondanks" die materieel oordadige maar menslikemosioneel banale ruimte gekonstitueer deur die saamwees en die besittings van die "spul mense" (p. 13) "begin - al is dit ver - die harde slae van die see teen die rotse met tussenposes hoorbaar word" (p. 15). Die see as simbool vir die vryheidsdrang van die menslike gees (waaraan ook hierdie gevange "idiote" deel het) oorstem die oënskynlik vol, maar in werklikheid leë, ruimte.

Op p. 12 word die wyse waarop stellings in koerantopskrifte gewoonlik verkort word, weergegee: "Jong meisie verkrag en toe vermoor ..." en "Jong mediese dokter betrokke in ANC-komplot". Hierdie werkwyse het vir die koerantwese nie 'n stilistiese oogmerk nie en is bloot 'n funksionele procédé. Binne die konteks van die verhaal demonstreer dit ook iets van die versaakliking (verdingliking) van die mens binne die moderne Westerse samelewing. Hierdie assosiasie word versterk deur die elliptiese mededeling: "Lees gou die opskrif- 
te" (p. 12) in plaas van "Hy lees gou die opskrifte" binne dieselfde paragraafverband.

\subsection{Woordorde}

In hierdie afdeling word gefokus op gevalle waar daar afgewyk word van die normale woordorde binne sinsverband.

Die eerste voorbeelde van gewysigde woordorde as nadruksmiddel kom op p. 12 binne die bestek van dieselfde paragraaf voor: "By 'n winkel waar dit lyk asof alles van plastiek gemaak is [...] koop hy 'n koerant [...]. Met sy hande in sy jassakke en die koerant onder sy arm stap hy oor die brug". Die uitstel van die sinsgedeeltes ("hy koop" en "hy stap") deur die frases "by 'n winkel" en "met sy hande" voorop te stel, sluit sintakties aan by die paradigma van ontmensliking waardeur hierdie paragraaf gestruktureer word, waarvan die verwysing na 'n meisie wat verkrag/vermoor is, waarvan die koerante "vol" was, asook dié na die winkel "waar dit lyk of alles van plastiek gemaak is", deel vorm. Die gewysigde woordorde in die eerste sin aksentueer die winkel (sentrum van die materialisme). Boonop is hierdie winkel 'n toonbeeld van onegtheid/kunsmatigheid: "dit lyk of alles van plastiek gemaak is". Dit is in hierdie verband veelseggend dat daar in die tweede paragraaf op p. 14 onder andere verwys word na "die gebruik van plastiek in die boubedryf". In die tweede sin word eers gefokus op die karakter se hande (in sy jassakke) en op die koerant (onder sy arm) voor daar by die persoonlike voornaamwoord hy uitgekom word. Ook dit sinjaleer die motief van verontmensliking.

Dieselfde procédé word gevolg in die uitgebreide sin op p. 14-15 waarna reeds hierbo verwys is. Die hoofsin ("die harde slae van die see (begin) [...] hoorbaar word") kom aan die einde voor van 'n reeks bysinne wat oor 26 reëls (6 paragrawe) versprei is. Die sin fokus derhalwe allereers op die banale optredes en gespreksonderwerpe van die partytjiegangers, daarna op die toneel aan die etenstafel, die ruimte buite wat "vergete raak" (insluitende "die skiër op die water"), om uit te mond in die moment wanneer die luukse interieur "begin grense en topografie en verlange word" (kursivering - MJP). Deur die uitsteltegniek word 'n gevoel van afwagting by die implisiete leser geskep as gevolg waarvan die verwysing na die see 'n klimaksale funksie verkry.

In die sesde paragraaf op p. 16 word, by wyse van kontras, in 'n uiters kort sin weer op die see gefokus: "As dit stil is, hoor 'n mens die see". Hier beklemtoon die ongewone woordorde die voorwaarde 
(stilte) om die "see" te kan hoor. Om werklik met die dieper dimensie van die lewe kontak te maak, moet die (moderne) mens weer leer om stil te word.

In die derde paragraaf (p. 9) word die plekaanduidende woord binne deur ongewone woordorde beklemtoon: "Binne lyk die huis byna bekend, die meubels, die gordyne, die skilderye." En in die sesde paragraaf van die einde af word die antoniem buite op dieselfde wyse gereleveer wanneer die visioen wat die sentrale karakter deur die bewasemde ruit van die sauna sien, beskryf word: "Buite op die rivier ry 'n boot rond, 'n motorboot, en uit die water uit staan 'n meisie op, 'n jong meisie, en haar rok wapper in die wind, in die son, dit wapper." (p. 17.) Op hierdie wyse word oor 'n groot afstand binne die teks die ironiese kontras tussen die binne-wêreld van die karakters (hulle gevangenisskap) en die vryheid en vitalisme buite beklemtoon.

Wanneer die meisie in bogenoemde visioen vir die sentrale karakter wink, laat dit hom besef: "Netnou is dit tyd. Dan sal almal sien ons is sterk genoeg." (p. 17.) Hierdie meisie is simbool van die vryheid waarna hulle smag, hulle verlange na die tyd wanneer die "idiote" vrygelaat kan word om "'n lewe (te) maak" (p. 17), werklik te bestaan as mense. Deur die beginreleverende woordorde ("Netnou is dit" in plaas van "Dit is netnou" en "Dan sal almal sien" in plaas van "Almal sal dan sien") word die bywoorde van tyd netnou en dan beklemtoon. Hierdeur word die oortuiging van die sentrale karakter benadruk dat daar vir hom en die ander "idiote" wat deel vorm van sy leefwêreld, 'n tyd van eksistensiële bevryding sal aanbreek.

\subsection{Ritme}

In sy biografie oor Etienne Leroux, Leroux: 'n lewe, haal Kannemeyer (2008:353) die volgende opmerking van Eddie du Plessis oor Leroux aan: "As mens elke roman byna woord vir woord met Stephen deurgegaan [...] het, het jy gou besef watter waarde hy heg aan die klank en ritme van 'n sin." Wanneer 'n mens die klank en ritme van De Vries se verhale onder die loep neem, kom jy tot dieselfde gevolgtrekking wat hom betref. Hiervan is daar ook talle voorbeelde in "Die uur van die idiote".

Op p. 9 kom die volgende sin byvoorbeeld voor: "Binne lyk die huis byna bekend, die meubels, die gordyne, die skilderye." Ons sou die ritme van hierdie sin soos volg kon aandui: 


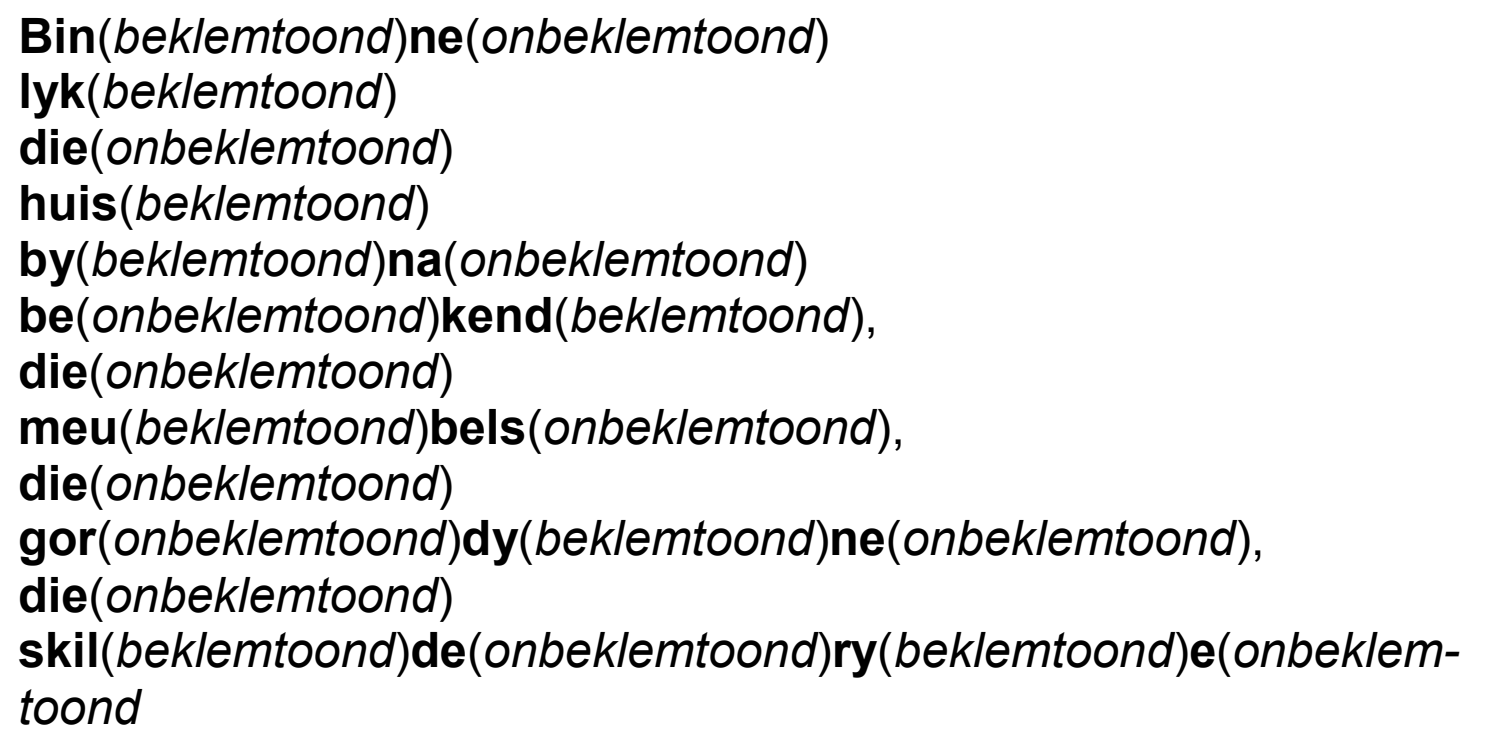

Indien ons die woordorde in die eerste gedeelte normaliseer, sien die ritme soos volg daar uit:

Die(onbeklemtoond)

huis(beklemtoond)

lyk(beklemtoond)

bin(beklemtoond)ne(onbeklemtoond)

by (beklemtoond)na(onbeklemtoond)

be(onbeklemtoond)kend(beklemtoond).

Dit bring mee dat ons 'n opeenvolging van beklemtoonde lettergrepe kry waardeur huis, lyk en bin(ne) beklemtoon word. Soos die sin in die teks georganiseer is, is daar 'n opeenvolging van beklemtoonde lettergrepe tussen huis en by(na). Daardeur word eksklusief hierdie twee (vir die strekking van die verhaal semanties belangrike woorde) beklemtoon deur die ritmiese afwyking van die res van die sin, waarin geen opeenvolging van beklemtoonde lettergrepe voorkom nie. In die normale woordvolgorde is daar 'n groter afstand tussen huis en byna, as gevolg waarvan hierdie twee woorde minder klem ontvang, terwyl lyk en bin(ne) meer klem ontvang. Deur die jukstaponering van huis en byna word die ironiese paradoks beklemtoon: byna alles in die huis laat die sentrale karakter voel asof hy "in 'n bekende plek verdwaal het" (p. 9). 'n Woonhuis is konvensioneel 'n bekende plek vir sy bewoners, maar die woord byna kommunikeer die eksistensiële ontreddering van die nuusredakteur.

Soos ook in die poësie die geval is, is die ritme in die prosateks dikwels 'n emosionele kode. Op p. 11 word gefokus op die gevoelens van die sentrale karakter en sy vrou. Dit gebeur byvoorbeeld in die volgende sin, waarin sy haar eggenoot se emosies diagnoseer: "Sy skuldgevoel gebruik soos kanker alles wat normaal is in hom en bly 
self morbied voortbestaan." Hierdie sin kan soos volg geskandeer word:

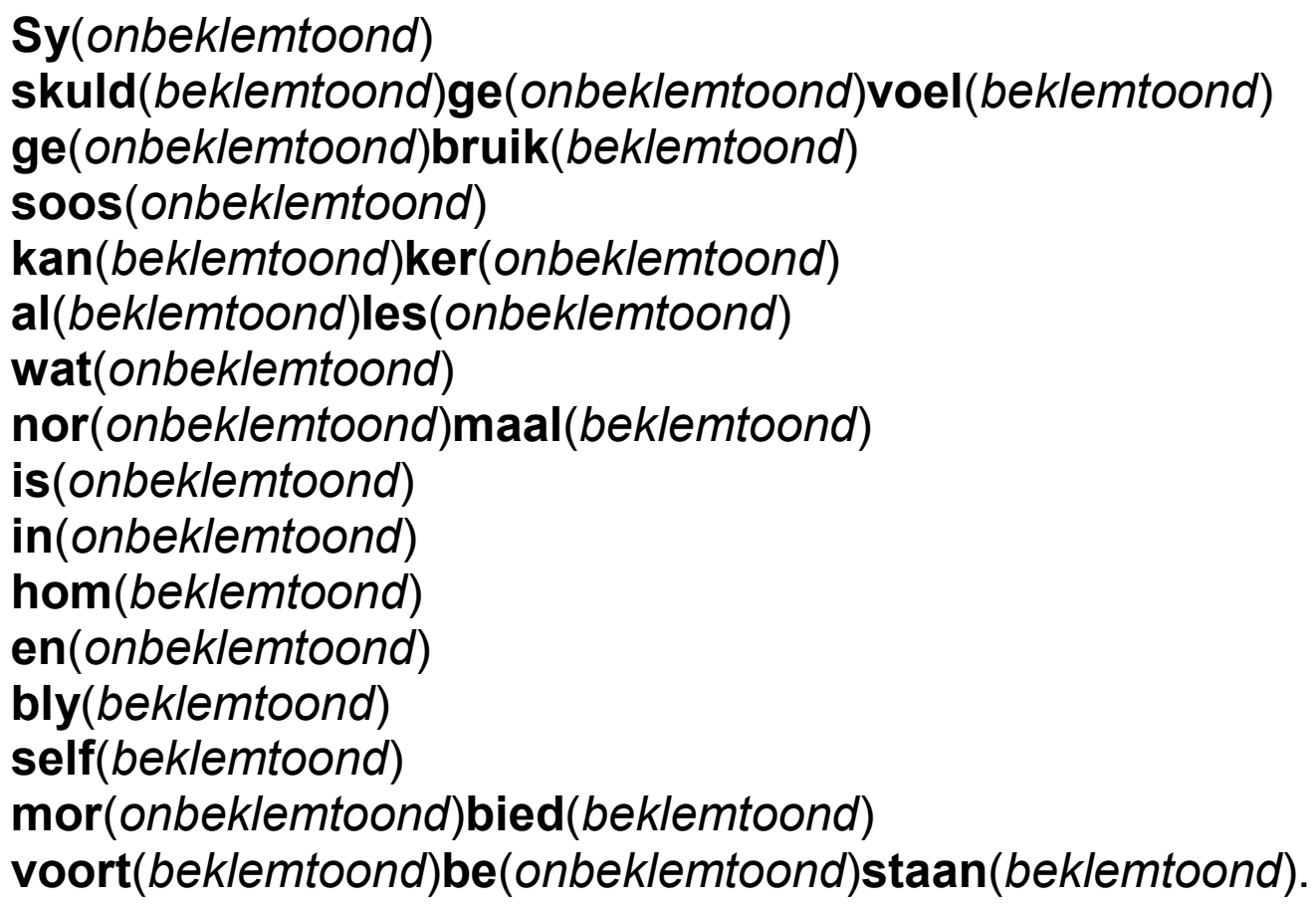

Die jambiese maat van die eerste tien lettergrepe (van sy tot al-) word vanaf die elfde lettergreep versteur deur die opeenvolging van beklemtoonde en onbeklemtoonde lettergrepe. As gevolg daarvan word die woorde normaal (voorafgegaan deur drie onbeklemtoonde lettergrepe en gevolg deur twee), bly (gevolg deur 'n beklemtoonde lettergreep), self (voorafgegaan deur 'n beklemtoonde lettergreep) en morbied (eindig op 'n beklemtoonde lettergreep) en voortbestaan (begin met ' $n$ beklemtoonde lettergreep) gereleveer. Deur die opheffing van die metrum word die versteuring van die "normale" voelbaar gemaak in die ritme van die sin. En deur die opeenvolging van beklemtoonde lettergrepe in bly en self word die dominansie van die "skuldgevoel" ook ritmies gekommunikeer.

Op p. 11 kom die volgende sin voor: "Die water in die riviermond het weggetrek met die gety en al wat onder die grys lug oorbly, is 'n kou moeras." Die tweede gedeelte is, ook wat die ritme betref, om twee redes interessant: die ongewone woordorde as gevolg van die verskuiwing van die onderwerp ("kou moeras") na die einde, en die gebruik van die variant "kou" in plaas van "koue". "Kou" kom as byvoeglike naamwoord nie voor in die 2000-uitgawe van die HAT nie. In Hauptfleisch (1991:28) kom dit voor, maar word as "' $n$ minder gebruiklike, verouderende attributiewe vorm van koud" beskryf.

Wat sinsvolgorde betref: indien ons die woordorde sou normaliseer na "'n kou moeras is al wat onder die grys lug oorbly", sou dit ritmies 
gesproke twee gevolge hê. Die sin sou eindig op 'n onbeklemtoonde lettergreep:

oor(beklemtoond)bly(onbeklemtoond) in plaas van op 'n beklemtoonde:

moe(onbeklemtoond)ras(beklemtoond).

Ook sou "(K)ou moeras" nie voorafgegaan word deur drie onbeklemtoonde lettergrepe nie:

oor(beklemtoond)bly(onbeklemtoond 1)

is(onbeklemtoond 2)

'n(onbeklemtoond 3).

Die neerdrukkende toneel wat die sentrale karakter hier waarneem, bereik 'n hoogtepunt in die verwysing na die moeras; daarom is dit ritmies-affektief funksioneel dat die sin op 'n beklemtoonde lettergreep eindig. Verder word die frase "kou moeras" gereleveer deurdat dit deur drie onbeklemtoonde lettergrepe voorafgegaan word. Die emosie wat die karakter ervaar, word effektief deur die sinsritme gekommunikeer. Hierdie koue moeras vorm ook 'n aangrypende kontras met die rivier waaruit die winkende meisie in die slotparagrawe van die verhaal opstaan - pragtige metafore vir dood en hergeboorte.

Die gebruik van kou in plaas van koue is ritmies funksioneel, aangesien dit die opeenstoting van twee beklemtoonde lettergrepe "kou"(beklemtoond 1) en "moe-"(beklemtoond 2) tot gevolg het. Daardeur verkry die emosioneel gelaaide byvoeglike naamwoord kou ekstra relevansie.

Die uitgesponne sin wat op p. 14 met "Nadat Bester" begin en op p. 15 met "hoorbaar word" eindig, is versprei oor sewe paragrawe wat slegs twee keer met ' $n$ vanselfsprekend beklemtoonde lettergreep begin, naamlik "nadat" (p. 14) en "ondanks" (p. 14). Interessant is die situasie met toe, die enigste woord waaruit die vyfde nuwe paragraaf op p. 14 bestaan. Hoewel die outeur nie aksenttekens gebruik om hierdie woord te beklemtoon nie, kan 'n mens nie anders as om dit as beklemtoond binne die sinsritme te lees nie, en wel om twee redes, naamlik dit is die enigste woord waaruit hierdie paragraaf bestaan en tweedens word dit voorafgegaan en gevolg deur kommas. Dit word onmiddellik gevolg deur "ondanks", wat met 'n beklemtoonde lettergreep begin, 'n opeenstoting van beklemtoonde lettergrepe as gevolg waarvan albei hierdie woorde ritmies gereleveer word. Dit is semanties funksioneel dat genoemde twee woorde op hierdie wyse beklemtoon word. Die hoorbaar word van "die harde slae van die see teen die rotse" (p. 15) is, soos reeds opgemerk, 'n 
betekenisvolle moment in die eksistensiële krisis waarbinne die karakters hulle bevind.

Die relevering van ondanks gryp terug na p.11, waar die nuusredakteur se vrou "'n bietjie wrang" dink: "Ondanks ... ondanks, want sy is jonk en sy weet dat sy nie onaantreklik is nie." Op p. 1415 word die slae van die see hoorbaar ondanks "die breë stoep en die toe luike aan die oostekant, en die volvloermatte en die netjies versteekte Mozart [...] en die Land-Rover van die polisie". Deur hierdie herhaling en beklemtoning word 'n verband gelê tussen die emosionele krisis waarbinne die vrou haar bevind (haar gevoelens van opstand en magteloosheid) en die eksistensiële leegheid (ten spyte van die materiële volheid van die ruimte waarbinne hulle hulle bevind) van die mense by die partytjie.

Die rol wat die komma as ritmiese komponent (na toe) in die hierbo aangehaalde gedeelte speel, is ook van belang vir die volgende sin op p. 16: "As dit stil is, hoor 'n mens die see." Hierdie sin kan ook soos volg gestruktureer word: "n Mens hoor die see as dit stil is." Tussen hierdie sin en die een in "Die uur van die idiote" is daar twee verskille. Dit bevat naamlik geen komma nie, maar 'n opeenstoting van beklemtoonde lettergrepe: "mens" (beklemtoond) en "hoor" (beklemtoond). Die komma in die tekssin is funksioneel, omdat dit as 'n ritmies-grafiese simbool dien vir die stilte waaroor die sin dit het. Die afwesigheid van 'n opeenstoting van beklemtoonde lettergrepe verleen eweneens iets rustigs (iets stils) aan die sinsritme. So word die noodsaak van psigiese stilte as voorwaarde vir die geestelike regenerasie van die karakters beklemtoon.

\subsection{Lengte en samestelling}

In 'n literêre prosateks kan sinslengte (wat ook saamhang met die samestelling en kompleksiteit van die sin) 'n struktureel-semanties belangrike kode wees. So kan 'n lang sin op begrippe soos volheid, oorvloed, kompleksiteit, ensovoorts dui en 'n kort sin op betekenisse soos bondigheid, onvriendelikheid, soberheid, ensovoorts. Die uiters lang, gelaaide sin op p. 14-15 (as simbool van die ironiese materiële "volheid" van die karakters se bestaan), waarby reeds hierbo stilgestaan is, kom dadelik by ' $n$ mens op. In teenstelling daarmee is daar die uiters kort tweede sin van die verhaal, "Boonop swart geverf" (p. 9), waarop ook reeds in afdeling 2.3 gefokus is.

Die vyfde paragraaf van die verhaal (p. 9-10) bestaan uit drie sinne: "Dié tyd van die jaar is hier nie baie vakansiegangers nie en die inwoners van die stranddorp is min."; "Dis hoekom hulle (sy) die plek 
uitgekies het."; en "Hulle vriende was jaloers op hulle, want almal droom, maar almal kan nie by die koerant, die skool, die bank of die firma bedank nie."

Die eerste sin bevat twee stellings: "Dié tyd van die jaar is hier nie baie vakansiegangers nie"; en "[Dié tyd van die jaar] is die inwoners van die stranddorp min". Die derde bevat weer drie stellings: "Hulle vriende was jaloers op hulle"; "almal droom"; en "almal kan nie [...] bedank nie". Hierteenoor bevat die tweede sin slegs een eksplisiete stelling: "Hulle (sy) het die plek uitgekies". Benewens hierdie stelling, bevat dit twee implisiete stellings: "Dis" verwys anafories terug na die stellings wat in die voorafgaande sin gemaak is as redes vir hulle keuse, en die invoeging van "sy" tussen hakies impliseer dat dit in werklikheid háár besluit was, hoewel hy klaarblyklik ook daarmee akkoord gegaan het.

Die tweede sin is ook veel korter as die ander. Dit vorm dus in meer as een opsig ' $n$ variant op die ander twee. Semanties is dit relevant dat hierdie sin, wat fokus op die (versteurde) verhouding tussen die egpaar as 'n kerngegewe in die verhaal, op dié wyses vooropgestel word.

Die afwisselende sinslengte skep 'n effektiewe oorkoepelende ritme in die vierde nuwe paragraaf op p. 11:

Ondanks, dink sy 'n bietjie wrang, ondanks, want sy is jonk en sy weet dat sy nie onaantreklik is nie. Selfs haar naaktheid - en sy hou daarvan om in deurskynende kaftans deur die huis te loop as hulle alleen is - selfs dit is meermale nie meer genoeg nie. Sy skuldgevoel gebruik soos kanker alles wat normaal is in hom en bly self morbied voortbestaan. En waarom? Daar is geen rede voor nie. Daarom maak dit haar magteloos.

Die aantal woorde per sin sien soos volg daar uit:

\begin{tabular}{|l|l|}
\hline $\operatorname{Sin} 1$ & 20 \\
\hline $\operatorname{Sin} 2$ & 28 \\
\hline $\operatorname{Sin} 3$ & 16 \\
\hline $\operatorname{Sin} 4$ & 2 \\
\hline $\operatorname{Sin} 5$ & 6 \\
\hline $\operatorname{Sin} 6$ & 5 \\
\hline
\end{tabular}

Daar is aanvanklik 'n toename in sinslengte van 20 na 28 woorde, dan 'n afname na 16, gevolg deur 'n skerp daling na 2 en 'n geringe 
toename na 6 en 5 . Hierdie ritme dien as nie-semantiese relevering van die emosionele gewaarwordings van die vrou. Haar gemoedstoestand wissel van 'n gevoel van wrangheid na een van verwerping, na magteloosheid. Die lang sinne kommunikeer eersgenoemde twee emosies effektief; so ook die kort sinne wat die derde emosie betref.

Die eerste nuwe paragraaf op p. 12 lui soos volg:

Op die krop van sy maag trek 'n vuis saam, asof hy vir iets bang is. Hy draai by die verlate swemplek om en stap in die rigting van die brug oor die rivier. As hy ver genoeg stap, sal die gevoel verdwyn. Of as hy by die hotel instap en iets gaan drink. Maar daarvan het hy ook al genoeg. Anderkant die brug dreun 'n boot op die rivier. 'n Skiër staan stadig op uit die water uit, soek gebukkend na balans terwyl hy die trektou styf vashou en dan begin hy in wye halfmane sy vastigheid tart. Toe die boot se motor gaan staan, sink hy weer in die water weg. Hy roep na die bestuurder wat sukkel om die enjin aan die gang te kry.

Die aantal woorde per sin is soos volg:

\begin{tabular}{|l|c|}
\hline $\operatorname{Sin} 1$ & 16 \\
\hline $\operatorname{Sin} 2$ & 18 \\
\hline $\operatorname{Sin} 3$ & 9 \\
\hline $\operatorname{Sin} 4$ & 11 \\
\hline $\operatorname{Sin} 5$ & 5 \\
\hline $\operatorname{Sin} 6$ & 9 \\
\hline $\operatorname{Sin} 7$ & 29 \\
\hline $\operatorname{Sin} 8$ & 14 \\
\hline $\operatorname{Sin} 9$ & 15 \\
\hline
\end{tabular}

Wat dadelik op val, is die lang sewende sin, waarin gefokus word op die prekêre spel wat die skiër met sy "vastigheid" speel. In hierdie fase van die verhaal dink die sentrale karakter aan die "storie" wat hy wil skryf oor 'n man wat na 'n waarsêer toe gaan, maar uitendelik in 'n eksistensiële krisis beland omdat hy nie meer in "die leuen" kan glo nie. Die koerantredakteur-skrywer ervaar heel letterlik sy eie soort eksistensiële angs van meelewing met die karakter in sy verhaal, soos deur die eerste sin van genoemde paragraaf uitgespel word: "Op die krop van sy maag trek 'n vuis saam, asof hy vir iets bang is." (p. 12.) Die skiër na wie binne dieselfde paragraafverband verwys word, funksioneer as simbool vir die "spel" (met die waar- 
heid) waarmee die karakter in die redakteur se verhaal besig was, en by uitbreiding ook vir die redakteur se eie eksistensiële onsekerheid as ontgogelde mens wat voel dat hy nie meer in die "leuen" kan glo nie. Dit is funksioneel dat die betrokke sin opvallend langer en meer kompleks is as die ander.

Die spel met sinslengte in "Die uur van die idiote" bereik 'n hoogtepunt in die lang sin wat van p.14-15 oor ses paragrawe strek, waarby reeds hierbo stilgestaan is. Hierdie sin demonstreer deur sy buitengewone lengte die ironiese "volheid" (leegheid) waardeur die aandbyeenkoms as "uur van die idiote" gekenmerk word.

Hy tel die Hemingway op, maar blaai nie daarin nie en soek nie na die plek waar hy laas gelees het nie. Hy dink: ons het niks om so oor te word nie: Sy het 'n man liefgehad en hy het haar misbruik en sy het in die tronk beland, dis maar nou eers dat sy poker speel met die polisie en vir kinders stories lees. lets het haar laat uitbreek. lets het haar weggeruk. Dis waarop ons almal wag. (p. 15, par. 7.)

In bostaande paragraaf besef die sentrale karakter in watter opsig Jana van hom en sy vrou en kennisse verskil. "lets het haar laat uitbreek. lets het haar weggeruk. Dis waarop ons almal wag." Hierdie "iets" is die vermoë om jou geskiedenis te transendeer deur op te hou om 'n magtelose slagoffer daarvan te wees. As mens wie se liefde daarop uitgeloop het dat sy misbruik is en in die tronk beland het, het Jana die vermoë gehad om daarbo uit te styg en voort te gaan om selfloos liefde en vriendskap te bewys. Sy doen dit deur vir kinders stories te lees en poker te speel met die polisie.

Die sinslengtes van die betrokke paragraaf (in terme van woorde) is soos volg:

\begin{tabular}{|l|r|}
\hline $\operatorname{Sin} 1$ & 22 \\
\hline $\operatorname{Sin} 2$ & 11 \\
\hline $\operatorname{Sin} 3$ & 33 \\
\hline $\operatorname{Sin} 4$ & 5 \\
\hline $\operatorname{Sin} 5$ & 4 \\
\hline $\operatorname{Sin} 6$ & 5 \\
\hline
\end{tabular}

Wat opval, is die opeenvolging van die volgende drie kort sinne onmiddellik na die langste sin in die paragraaf. "lets het haar laat uitbreek. lets het haar weggeruk. Dis waarop ons almal wag." Hierdie kontras in sinslengte is funksioneel. Enersyds dra die lang sin iets 
oor van die veelbewoë verlede van die vrou. Andersyds kommunikeer die hortende kort sinne iets van die eksistensiële gebondenheid van die "ons".

Wanneer die gaste besig is om tot siens te sê, dink die sentrale karakter:

Nag, nag, goeie mense, nag. Kyk na my hand. Dit wuif. Kom weer. Kom weer. En weer. Slaap gerus. Die ergste wat met ons kan gebeur, het al gebeur. (p. 16.)

Hierdie paragraaf word gekenmerk deur 'n buitengewoon hoë aantal kort sinne. Weer suggereer die kort staccatosinne, geïntensiveer deur die hoë frekwensie van woordherhaling, die sentrale fokalisator se magteloos-siniese perspektief op sy gaste (asook op homself) as goeie mense, waardige verteenwoordigers van die dehumaniserende verbruikerskultuur.

Sinslengte hang gewoonlik ook saam met sinskompleksiteit. Hoe langer ' $n$ sin is, hoe meer saamgesteld is dit gewoonlik. Die eerste twee sinne van die sewende paragraaf op p. 16 sien byvoorbeeld soos volg daaruit. "Hy gooi water op die verwarmer omdat die lug droog geword het en in almal se kele brand en die mis wat smiddags uit die see opkom, wasem opnuut teen die ruite aan. Alles is ondeursigtig." Die eerste sin het twee hoofsinne, naamlik "Hy gooi water op die verwarmer", en "Die mis wasem teen die ruite aan". Daarbenewens bevat dit drie bysinne, naamlik "Die lug het droog geword"; "(Die lug) brand in almal se kele"; "Die mis kom smiddags uit die see op". Daarteenoor bestaan die tweede sin uit 'n enkelvoudige stelling, ingelei deur die anaforiese "alles". In hierdie paragraaf ervaar die sentrale karakter sy eksistensiële onmag op mikrovlak: Hy kan nie deur die ruite sien nie en ook nie die deur oopkry nie. Albei gegewens word metafore vir geestelike uitsigloosheid en onmag/gevangenisskap as topoi van die verhaal. Die kompleksiteit van die eerste sin is 'n strukturele kode vir die ingewikkeldheid van sy situasie. Die kort, enkelvoudige tweede sin dien as samevatting van die situasie wat in die eerste geskets is en kommunikeer beklemtonend die gevolg daarvan.

\subsection{Klankherhaling}

Klankherhaling (alliterasie, akkonsonansie en assonansie) word tradisioneel as 'n tegniek van die poësie beskou. Tog kan dit ook 'n belangrike funksie in die literêre prosateks hê. Die eerste sin van "Die uur van die idiote" laat reeds iets hiervan blyk. "Nie 'n see nie 
(and a star to steer me by), nee, in die stad was daar nie 'n see nie, maar om die huis was daar ook nie 'n heining van gegote ystertralies nie." (Kursivering en vetdruk - MJP.) In die eerste plek val die $s$-alliterasie in "see", "star", steer", "stad" op, sowel as die akkonsonansie daarvan in "huis" en "ystertralies". Tweedens is daar die eeassonansie tussen "see", "steer", en "nee". Deur hierdie herhaling word die aandag klankmatig gevestig op begrippe wat vir die res van die verhaal belangrik is. Die see word simbool van die sentrale karakter se drang om sy eksistensiële gevangenisskap te verbreek. Die star sluit aan by die behoefte aan 'n lewenskoers of lewensin. Die woord stad is belangrik, omdat dit die ruimte benoem waaruit die hooffiguur (ironies genoeg) padgegee het om weg te kom van sy probleme. Die akkonsonansie tussen "huis" (wat ook met "heining" allitereer) en "ystertralies", lê klankmatig 'n ironiese verband tussen die konsepte tuiste en gevangenis.

In paragraaf 4 op bladsy 9 word 'n boeiende spel met klankherhaling gespeel. "Drie maande, en alles het al weer bekende patrone aangeneem. Binne lyk die huis byna bekend, die meubels, die gordyne, die skilderye. Behalwe die stok en katrol op die stoep en die pitlamp onder die growwe visnet wat tussen die balke gespan is, laat alles hom voel asof hy in 'n bekende plek verdwaal het." (Vetdruk - MJP.) Die woord bekend/e is veelbetekenend vir die ironie van die situasie waarin die sentrale karakter hom bevind. Hy voel "asof hy in 'n bekende plek verdwaal het". Dit word eerstens gereleveer deur die feit dat dit drie keer binne die bestek van 'n paragraaf wat slegs uit drie sinne bestaan, voorkom. Tweedens deurdat dit allitereer met "begin", "byna", "behalwe" en "balke", asook akkonsoneer met "meubels". Die woord bekend kom slegs twee paragrawe verder nogeens voor. "Die boeke, die skryftafel, die liasseerkabinet in sy studeerkamer, die Breughelafdruk bokant die kaggel, alles is bekend, maar teen die laatmiddag as die mis van die see se kant af begin opkruip, slaan die vensters aan die binnekant aan, selfs al brand die vuur." (p. 10; vetdruk - MJP.) Weer word dit klankmatig vooropgestel deur die alliterasie en akkonsonansie met "boeke", "-kabinet", "Breughel-", "bokant", "begin", "binnekant" en "brand". Die verband wat alliterasie en akkonsonansie tussen die betrokke woorde lê, releveer die ironiese paradoks tussen die twee dele van die sin, dié voor die voegwoord "maar" en dié daarná. Die huislikheid van die ruimte (waarvan die kaggelvuur by uitnemendheid 'n verteenwoordiger behoort te wees) is skyn, want daar is geen psigies-geestelike uitsig nie. 


\section{Samevatting}

De Vries is, ook wat sy hantering van die sin as narratiewe kode betref, meester van sy ambag. Die digte weefsel van woord- en fraseherhaling wat sy sinne soms kenmerk, ironiseer en/of aksentueer die eksistensiële situasie van die karakters. Enumerasie staan in diens van die ironiese paradoks tussen materiële "volheid" en geestelike "leegheid" waaroor die verhaal basies handel. Ellips sinjaleer die motiewe van verlies, ontnugtering en versaakliking. Gewysigde woordorde vestig die implisiete leser se aandag op woorde en frases wat tematies relevant is. Die sinsritme dien as ' $n$ emosioneelsemantiese kode. Sinslengte en -samestelling demonstreer die geestelike uitsigloosheid en onmag van die karakters. Klankherhaling vestig die leser se aandag op begrippe wat vir die verhaal belangrik is.

\section{Geraadpleegde bronne}

CARSTENS, W.A.M. 1997. Afrikaanse tekslinguistiek. Pretoria: Van Schaik. CLOETE, T.T., red. 1992. Literêre terme en teorieë. Pretoria: HAUM-Literêr.

DE VRIES, A. 1984. Dictionary of symbols and imagery. Amsterdam: NorthHolland Publishing Company.

DE VRIES, A.H. 1980. Die uur van die idiote. Kaapstad: Human \& Rousseau.

DE VRIES, A.H. 1989. Kortom2: gids by die Afrikaanse kortverhaalboek. Kaapstad: Human \& Rousseau.

DU TOIT, P.A. 1998. Abraham H. de Vries (1937-). (In Van Coller, H.P., red. Perspektief en profiel. Deel 1. Pretoria: Van Schaik. p. 388.) HAT

kyk ODENDAL \& GOUWS

HAUPTFLEISCH, D.C., red. 1991. Woordeboek van die Afrikaanse taal. Stellenbosch: Buro van die WAT.

KANNEMEYER, J.C. 1983. Geskiedenis van die Afrikaanse literatuur. Band 2. Pretoria: Academica.

KANNEMEYER, J.C. 2008. Leroux: lewe. Pretoria: Protea Boekhuis.

ODENDAL, F.F. \& GOUWS, R.H. 2000. Verklarende Handwoordeboek van die Afrikaanse Taal. Kaapstad: Perskor.

SMUTS, J.P. 1985. Burgerband. Kaapstad: Tafelberg.

VAN ZYL, W., samest. 2007. Elke slot 'n weerbegin. Belville: Universiteit van Wes-Kaapland.

\section{Kernbegrippe:}

De Vries, A.H.

kortverhaal

sin as narratiewe kode 


\section{Key concepts:}

De Vries, A.H.

short story

syntax as narrative code 